\title{
Geoffrey Chaucer'in Canterbury Hikâyeleri Eserinde Toplumsal Cinsiyetin Sorunlu Temsili
}

\author{
Emrah ATASOY*
}

ÖZ

Geoffrey Chaucer'ın hacıların anlattıkları 24 hikâyeden olușan Canterbury Hikêyeleri adlı eseri, yazarın yașadığı toplumun bir panoramasını sunmaktadır. Hacıların birbirlerine anlattıkları bu hikâyeler, kadın ve erkek tasvirleri, saraylı aşkı, şövalyelik, şeref ve dine bağlı yaşam gibi birçok konuyu ele almaktadır. Bu hikâyelerin kökenlerinde fabliau, romans, saraylı usulü aşk geleneği ve aziz efsanesi gibi kaynakları bulmak mümkündür. Toplumsal cinsiyetin tasviri, bu hikayelerde oldukça önemli bir rol oynamaktadır. Bu rollerin tasvir edilmesi, kadınların bu hikâyelerde nasıl bastırıldıklarını da ortaya çıkarmaktadır. Bu çalışma bu noktalardan yola çıkarak, Chaucer'ın Canterbury Hikâyeleri adlı eserinde yer alan "The Franklin's Tale," "The Physician's Tale" ve "The Man of Law's Tale" hikâyelerinde toplumsal cinsiyetin ve toplumsal cinsiyet rollerinin sorunlu tasvirini, bu hikâyelerde yer alan üç kadın karakterin kapsamlı incelemesi üzerinden tartışacaktır. Böylesi bir tartışma, bu hikâyelerde bahsi geçen kadın karakterlere ne gibi özellikler verildiğini; tarihsel, toplumsal ve edebî bir bağlam içerisinde hikâyelere ve konu ile ilgili ikincil kaynaklara göndermeler üzerinden ortaya koyacaktır.

Anahtar Kelimeler: Geoffrey Chaucer, Canterbury Hikâyeleri, "The Franklin's Tale," "The Physician's Tale," "The Man of Law's Tale," toplumsal cinsiyet

\section{The Problematic Representation of Gender in Geoffrey Chaucer's The Canterbury Tales}

\begin{abstract}
Geoffrey Chaucer's The Canterbury Tales, which contains 24 stories, presents a panorama of his society through the pilgrims' stories. These tales engage themselves with numerous issues such as the representation of women and men, courtly love, knighthood, honor, and pious life. These stories have different sources like fabliau, romance, the courtly love tradition, and saint's legend. The portrayal of gender plays a highly significant role in these tales that highlight the suppression of women. This study will, in this respect, discuss the problematic depiction of gender and gender roles through the detailed discussion of the female characters in the three selected tales in Chaucer's The Canterbury Tales, namely "The Franklin's Tale," "The Physician's Tale," and "The Man of Law's Tale." This discussion will ultimately reveal what kind of attributes these female characters are given in line with the historical, social, and literary context through numerous specific examples from the tales and relevant secondary sources.

Keywords: Geoffrey Chaucer, The Canterbury Tales, "The Franklin's Tale," "The Physician's Tale," "The Man of Law's Tale," gender
\end{abstract}

\section{Introduction}

There was a substantial difference between women and men in the Middle Ages due to the strong influence of the church and patriarchal rules that located women into certain restricted molds, which made women subordinate to men. Women in this regard could not go beyond the limits of this constrained world. They were given ingrained domestic roles and were expected to behave accordingly, whereas men were regarded as the decision-makers, which accentuates the fact that gender is constructed: "[G]ender is an act which has been rehearsed, much as a script survives the particular actors who make use of it, but which individual actors in order to be actualized and reproduced as reality once again" (Butler, 1988, p. 526). Gender is thus constructed "as a discursive category modulated by other social categories" (Lennox, 1991, p. 94). In this respect, gender should be perceived as a "mode of discourse that relates to groups of subjects whose social roles are defined by their sexual/biological difference" (YuvalDavis, 2009, p.52). Gender identities are constructed "in relation to each other and in relation to other terms with which they appear" (Nash, 1997, p. 67). Hence, to talk about "the notion of gender as a stable category" is not possible (Misra, 2018, p. 111).

Literary texts may illustrate and draw particular attention to the socially constructed nature of gender roles. Geoffrey Chaucer's The Canterbury Tales, one of such literary works, presents a panorama of its society with pilgrims of various professions. Since these pilgrims are to tell two tales on the way out and

* Assist. Prof. Dr., Cappadocia University, emrah.atasoy@kapadokya.edu.tr Makalenin Gönderim Tarihi: 26.11.2020; Makalenin Kabul Tarihi: 03.02.2021 
two tales on the way home, they recount their tales on women, men, courtly love, knighthood, honor, and pious life. These tales have different sources such as fabliau, romance, the courtly love tradition, and saint's legend. In one way or another, they are related with the illustration of women. "The Franklin's Tale" (a Breton lay, romance), "The Physician's Tale" (saint's legend) and "The Man of Law's Tale" (saint's legend) deal with the representation of women and how women were perceived in social, religious, and cultural context. This study will, therefore, discuss how women in these tales are depicted, and what kind of attributes they are given in line with the historical, social, and literary context through certain specific examples from the tales and relevant secondary sources.

\section{Discussion}

The plot summaries of the selected tales within the context of this article indicate how gender roles are portrayed. To start with, "The Franklin's Tale" is about the love of the Breton knight Arveragus and his wife Dorigen. At the beginning of the tale, the Franklin tells that it is an equal and happy marriage; however, when Arveragus is sent away, it is disrupted. Then, Dorigen finds herself in great agony. Her friends strive to console her, but she is worried that the rocks near the shore would kill her husband through a shipwreck. At a party organized by her friends, a squire named Aurelius that is handsome, young, and who has been in love with her for two years, declares his love for her; however, she does not accept him. Later on, she tells him that she would love him if he could remove all the rocks.

Aurelius finds a way to remove the rocks with the help of a student of law at Orleans who is skilled in illusion and magic. He agrees to remove the rocks for some time in return for a thousand pounds, and when he tells this to Dorigen, she is struck by surprise, awe, and grief which leads her to refer to many different women who have killed themselves before losing their reputation and maidenhood. When Arveragus returns home, Dorigen explains him everything. Upon this, he sends her to Aurelius since a promise cannot be broken once it is uttered according to him. When Aurelius sees this noble act, he agrees to send Dorigen back to Arveragus. He still wants to pay the student, but upon learning what Aurelius has done, the student does not charge him anymore. The tale ends with the question of the Franklin as to the issue of who is nobler.

"The Physician's Tale" is about a knight called Virginius and how he murders his daughter in order to protect her from rape and losing her name. This knight has a daughter that is humble, honorable, and beautiful. When she goes into the town for temple rites, a judge named Appius sees her and starts to plan how to possess her. Thus, he sends a churl named Claudius to make a false complaint about Virginius claiming that Virginius is illegally holding a daughter that does not belong to him. Upon this, the judge decides that the girl should be taken from him.

When Virginius returns home, he tells the situation to her with grief by stating that there are only two ways: either shame or death. Although the daughter asks for another solution rather than death, he expresses that there is unfortunately no other way. Upon this, she becomes consoled to know that she will die at least virgin. He cuts her throat and takes it to the judge. Then, Appius is put into prison where he kills himself and Claudius is sent into exile upon Virginius' wish. The tale ends with the warning of the physician to forsake sin.

In a similar vein, "The Man of Law's Tale" is about the suffering of a woman called Constance that experiences many hardships but is saved by divine power in the end. When some rich traders in Syria make a journey to Rome, they see Constance, the emperor's beautiful daughter. When they go back to Syria, they tell about her to the sultan. The sultan states that he can be Christianized rather than lose her. The Roman emperor agrees to this marriage; however, the sultan's mother does not agree since she does not want her son to marry a Christian. Therefore, she prepares a secret plan with her counsellors. When the Christians arrive in Syria for the feast, they are all killed save Constance.

The sultan's mother's men put her in a ship and she sails across the sea finally arriving in Northumberland. The warden of the castle and his wife, Hermengild gives her shelter there. Constance secretly converts the wife to Christianity and later on, the husband is converted as well. There, a young knight falls in love with Constance who does not return his love. Thus, he slits Hermengild's throat secretly and puts the blame on Constance. When the warden, the knight and the king of Northumberland, 
Alla gather, the knight insists that it is Constance who has killed Hermengild. When a hand strikes the knight by miracle, Constance is proved guiltless and the King is converted into Christianity upon this miracle. King Alla and Constance get married, but Donegild, Alla's mother is not happy about the situation. Constance gives birth to Maurice while Alla is in Scotland. Donegild prepares a plot through the forgery of the letters sent by Alla and Constance. When Alla finds out about it, he murders his mother. Constance is helped by Virgin Mary and they find themselves in Syria. The Roman army there brings Constance back to Italy. In Rome, King Alla recognizes Maurice when he is there for penance and forgiveness since he resembles Constance and soon sees Constance as well. Constance meets the Emperor and a happy atmosphere is created. Later, Maurice becomes the Emperor. Alla and Constance go back to England but Alla dies soon. Ultimately, Constance goes to Rome to find her father in the end.

As can be seen, female figures in these three tales are suppressed and manipulated by patriarchy. They are either slain or experience many difficulties. How these women are depicted in these tales has associations with the literary traditions out of which they are born such as romance or saint's legend. In this regard, Chaucer challenges these stereotypical images. To start with, the Franklin presents a female figure, Dorigen in his tale that is a Breton lay, a short romance. In order to comprehend the tale, it may be necessary to briefly explain Breton lay. Breton lays follow the general pattern of romance and projects "a sort of diagram of love's powers: devotion, fidelity, compassion, and fraternity" (Furnish, 2007, p. 101).

The courtly love tradition also plays a key role in understanding this tale since there are parts that are influenced by this tradition in the depiction of the female character. The lover sees the beloved and falls in love with her. The man idealizes the beloved in his eyes. Martin states that "[t]he lady is loved to the extent that she replaces God in the lover's eyes. His prayers are directed toward Venus, but worship belongs to his lady" (1972, p. 12). Woman "personified everything from true love, courtly love, good, evil, and everything else in the world of the man in romance literature" and became "his inspiration and often his downfall" (Warden, 2001, p. 25). Thus, woman is put on a pedestal in love and the knight has to perform certain deeds in order to gain her heart. Once her heart is won, the knight becomes the lord in marriage. However, the woman is not totally limited in her choice of suitor. Warden comments on this point as follows: "She had the right to choose a lover that best suited her and he must prove himself worthy of her graces and love. The men in courtly love are often seen as weak until he has won his beloved" (2001, pp. 29-30). Therefore, the knight proves himself worthy in love as well as in knighthood and chivalry so that he can gain his lady's love.

These features reflect the medieval society's treatment of women in social life. Women were "either praised for their physical beauty or virginity or reviled as temptresses who could ruin men" (Chao, 2007, p. 76). In this patriarchal structure, good women were "women who guarded their wombs so that men's legitimate offspring could be guaranteed" and they were identified as "chaste or unchaste" (Chao, 2007, p. 77). Obedience, humbleness, subordination, and self-sacrifice were expected from women. Bearing these remarks in mind, the question of how much Dorigen is influenced by these characteristics of the age and literary tradition becomes relevant.

The tale starts with the happy marriage of Arveragus and Dorigen, which offers an insight into the manipulative patriarchal discourse on women and the male-dominated nature of the marriage institution at the time. The lover promises the beloved that he will not desert her and mistreat her. In return for his promises, Dorigen promises as well: "Sire, I wol be youre humble trewe wyf-Have heer my trouthe-til that myn herte breste" (Chaucer, 1957, Lines 757-60). These remarks show that in marriage she will be in a lower status, though the narrator tells otherwise: "Love wol nat been constreyned by maistrye" (Chaucer, 1957, Line 764). In the following lines, the beloved takes the lover as servant in love and lord in marriage: "Thus hath she take hir servant and hir lord-Servant in love, and lord in marriage. Thanne was he bothe in lordship and servage. Servage? Nay, but in lordship above" (Chaucer, 1957, Lines 792-94).

When Arveragus is sent away for two years, Dorigen mourns, and weeps. It is recounted that she loves him so much that nothing can replace her love. However, the Franklin does not recount the process through which he gains her heart but instead tells that they are already married in the beginning. Her knight is made to go away and they are separated, one of the characteristics of a Breton lay and the courtly love tradition. During this period, a squire, Aurelius declares his love for Dorigen, but she maintains her 
loyalty to Arveragus. However, her decision about the rocks shows that she is not a completely passive figure. If Aurelius can remove the rocks, she promises to love him: "Thanne wol I love yow best of any man; Have heer my trouthe, in al that evere I kan" (Chaucer, 1957, Lines 997-98). Dorigen cannot commit adultery and love another man, as she is expected to be obedient and loyal.

Her reference to other women exemplifies how the patriarchal discourse has caused many women to slay themselves in order not to lose their virginity. Thus, women were in a way forced to commit suicide. To give other examples, fifty virgins from Sparta choose to die before they give assent. Stymphalides slays herself before losing her virginity. Hasdrubal's wife jumps into the fire in order not to suffer Roman's villainy. Lucretia chooses to die after she is ravished by Tarquin. Lastly, the seven maidens of Miletus slay themselves before the Gauls could give harm to them. Baker states that her reference to these women falls into three sections: "[W] omen who kill themselves before being raped, women who do so after being raped, and women who remain completely loyal to their husbands" (1961, p. 62). Thus, they are made to choose between death and loyalty to patriarchy.

Dorigen as a character who is aware of the condition of women does not want to live anymore, which she explains as follows: "I wol conclude that it is bet for me, To sleen myself, than been defouled thus. I wol be trewe unto Arveragus, or rather sleen myself in som manere" (Chaucer, 1957, Lines 1421-25). Her reference to other women such as Scedasus's daughters, the Thebian maiden raped by a Macedonian, Niceratus's wife, Alcestis, Penelope, Laodamia, Bilia, and Valeira is functional in that her "catalogue of classical women textualizes her anxiety over having to choose between fidelity to her husband and fidelity to her word" (Nowlin, 2006, p. 53). On the third night, Arveragus comes home and she tells everything to him. He insists that she keep her promise: "Ye shul youre trouthe holden, by my fay! For God so wisly have mercy upon me, I hadde wel levere ystiked for to be For verray love which that I to yow have, But if ye sholde youe trouthe kepe and save. Trouthe is the hyeste thyng that man meye kepe" (Chaucer, 1957, Lines 1474-79). Dorigen's fate is thus left at the hands of Arveragus. He even forbids her to talk about this incident. As can be seen, woman does not have the right to reject her husband's wish in this Breton lay.

In a similar vein, woman is expected to obey what the husband says in marriage, which is what happens in "The Franklin's tale." When Dorigen meets Aurelius, she says: "Unto the gardyn, as myn housbonde bad, My trouthe for to holde—allas, allas!” (Chaucer, 1957, Lines 1512-13). As can be seen, she does not question the order of Arveragus, but simply accepts the situation. However, Aurelius sends her back since he sees Arveragus's noble act. In this part, it is the male to be praised rather than the female: "Madame, seyth to youre lord Arveragus, That sith I se his grete gentillesse To yow, and eek I se wel youre distresse" (Chaucer, 1957, Lines 1526-28). Arveragus is referred to as her lord, which reflects the influence of the courtly love tradition where man is lord in marriage, whereas woman is his servant. Dorigen is happy with her husband in the beginning, but is to suffer in the aftermath of Arveragus's departure. She should "resist the importunate wooing of a passionate lover, whom she could only dismiss. . . by promising to grant him her love, on condition that he performed a seemingly impossible task" (Schofield, 1901, p. 407). She has a certain degree of freedom in her promise to Aurelius, but is deprived of her voice when she is to be sent to Aurelius by her husband. Dorigen is expected to have "mildness" and "humility" instead (Mann, 1966, p. 24). In the end, Dorigen and Arveragus re-unite and she succeeds in her test.

Similar to the first tale, the other two tales also demonstrate the problematic representation of gender and gender roles. It is important to present brief information about saint's legend prior to the textual discussion. Blalock and Larson comments on this literary tradition as follows: "[S]aints' legends, writings that recount and celebrate the lives, deaths, and posthumous miracles of men and women recognized as saints, comprised one of the dominant literary genres in Europe from Late Antiquity to the end of the Middle Ages" (2003, p.1). The main goal is to "glorify the memory of a particular saint, generally for such practical purposes as strengthening the morale of the community to which the saint had belonged, driving home some point of doctrine or morality, winning new adherents to the saint's way of life, or drawing pilgrims to the saint's shrine" (Blalock \& Larson, 2003, p. 1). Furthermore, the virgin martyr legend can be observed in this tradition. The female figure is presented as "a victim of male persecution rather than a 
female or androgynous figure of power" and she does not avoid pain (Blalock \& Larson, 2003, p. 3). These legends involve "the motifs of men lusting after a young and beautiful virgin saint, stripping her naked, torturing her body in various horrible ways, and eventually putting her to death" and the virgin's adversaries tend to be "the authority figures in her family or state, or both, and they are characterized more often as tyrants, infuriated by any disobedience to their orders, than as would-be rapists" (Blalock \& Larson, 2003, p. 4).

These characteristics can be seen in both "The Physician's Tale" and "The Man of Law's Tale." "The Physician's Tale" is a virgin martyr legend since the daughter of Virginius is a victim of Appius's lust. Lecherous Appius, a judge, has a wish to possess her, but he finally causes her death. In the end, Appius slays himself and Claudius is sent into exile. The narrator's depiction of this daughter idealizes her because nature as personified has molded and shaped her in a unique manner. Accordingly, she is given attributes such as virginity, humility, patience, abstinence, discretion, and temperance.

The narrator warns the audience not to take part in vice and sin, challenging the submission of women, and criticizing men's objectification of the woman body and women in general. He therefore says: "Looke wel that ye unto no vice assente" (Chaucer, 1957, Line 87). The narrator expresses the features of the daughter that are Mary-like features as follows: "She was so prudent and so bountevous. For which the fame out sprong on every syde, Bothe of hir beautee and hir bountee wyde" (Chaucer, 1957, Lines 11012). Thus, she is portrayed in an exaggerated and idealized manner. She is defined by the male in terms of having domestic features. Appius' name reflects his lecherous nature as well because it "resonates with the deponent Latin verb apiscor . . . meaning 'to reach after,' or 'to seize,' 'to get possession of,' 'to perceive,' just as Claudiu' name summons claudo, 'to close,' 'shut,' 'hem in,”' (Bloch, 1989, p. 118).

When the decision regarding the daughter is given by the judge, Virginius does not try to find a solution to the situation, but simply offers two options: either shame or death. This attitude causes her to suffer, which will bring her to a saint-like position, but the male finds in himself the right to kill even his daughter in order to protect her virginity: "Ther been two weyes, outher deeth or shame, That thou most suffer; allas, that I was bore! . . . Take thou thy deeeth, for this is my sentence" (Chaucer, 1957, Lines 214 24). Although he does not want to kill her and he knows that the judge has falsely judged, he ends up sacrificing his daughter. When the daughter hears what Virginius has told, she asks for another option in a submissive manner: "And seyde, Goode fader, shal I dye? Is ther no grace, is ther no remedye?" (Chaucer, 1957, Lines 235-36). It is possible to deduce from her remarks that this idealized female character does not want to die. However, she is finally made to agree to her death: "Blissed be God that I shal dye a mayde! Yif me deeth, er that I have a shame; Dootg with youre child youre wyl, a Goddess name!" (Chaucer, 1957, Lines 247-50). Her concern with her virginity reflects the medieval society's tremendous concern over maidenhood. In the end, the daughter, "personification of human perfection, falls victim to male lechery and paternal arbitrariness," drawing particular attention to the influence of the male dominant discourse (Fichte, 1983, p. 200).

As can be observed, the daughter is not given an active role in the decision about her. The tale therefore presents "the passive sacrifice of the virgin martyr, victimized by both justice and father, within a parable of passivity that extends all the way to the level of structure," which illustrates the silenced perspective (Bloch, 1989, p. 114). It is not only Appius in this case but also her father that cause her death. She is seen as an object, even when she is "the grammatical subject of a sentence she is the sufferer of an action" (Middleton, 1973, p. 21). Her suffering ultimately brings her to a saint-like status. Hence, it can be stated that it is the male lechery that brings death to the innocent female character in "The Physician's Tale."

The third tale, "The Man of Law's Tale" is a saint's legend with a female saint that experiences certain troubles but is saved by divine power each time. Constance is depicted in a very masculine manner by the men of the sultan: "In hire is heigh beautee, withoute pride, Yowthe, withoute grenehede or folye; Ta alle hire werkes vertu is hir gyde; Humblesse hath slayn in hire al tirannye. She is mirour of alle curteisye" (Chaucer, 1957, Lines 162-66). Her virtues, humility, maturity, courtesy, and holiness are accentuated in an idealized manner. Constance leads a saint-like life, which is the reason for the conversion of the sultan: "Rather than I lese Custance, I wol be cristned, douteless" (Chaucer, 1957, Lines 225-26). Despite this 
depiction, she is not totally silenced. She is agonized over the fact that she is to go to the Barbary nation: "Allas, unto the Barbre nacioun I moste anoon, syn that it is youre wille; But Crist, that starf for our redempcioun So yeve me grace his heestes to fulfille! I, wrecche womman, no fors though I spille! Wommen are born to thraldom and penance" (Chaucer, 1957, Lines 281-86). These remarks implicate and demonstrate that she questions the position of women in her society and the manipulation of women by men.

The sultan's mother that is an authority figure is the adversary of Constance in Syria because she does not want her son to be with a Christian woman. She lives by the word of Koran as she tells, but the plot she arranges against Constance and all the Christians at the feast does not match with her piety. Constance is saved by God as the only Christian that has not been killed by the sultan's mother's men. How she is saved is explained by the narrator in the following manner: "Who saved Danyel in the horrible cave, That every wight save he, maister and knave, Was with the leon frete er he asterte? No wight but God that he bar in his herte" (Chaucer, 1957, Lines 473-76). Divine intervention arrives, as she gets the help of Virgin Mary and finds herself in Northumberland. She conceals her identity when she meets the constable and Hermengild that are pagan. Constance does not lose time to convert Hermengild to Christianity: "Til Jhesu hath converted thurgh his grace Dame Hermengyld, constablesse of that place" (Chaucer, 1957, Lines 538-39). When the constable sees a miracle in which a blind Briton recognizes the converted Hermengild, he becomes Christian as well, as Constance explains that it is the power of Christ.

Her testing continues in Northumberland since she is to be blamed for murdering Hermengild, which manifests the pressure of the patriarchal structure over the female characters. A young knight falls in love with Constance, but since she does not return his love, he secretly slits Hermengild's throat and accuses Constance of the murder. However, she is saved once more by God when it is found that it is actually the knight that has killed Hermengild. In order to gain a woman, another innocent woman is slain by a young knight, which indicates the problematic aspect of the patriarchal discourse and hegemonic norms. A male figure slays another man's wife in order to appease his hunger for Constance.

Power given to a female character does not necessarily stand for empowering power, as it may worsen the situation for other female characters even further. The narrator touches on another woman, Donegild, King Alla's mother. She is similar to the sultan's mother in that she does not favor the marriage of Constance and King Alla. Although they have a baby called Maurice, this does not make Donegild happy, and finally causes Constance and Maurice to be sent away with the help of her forged letters. The narrator presents an Eve-like mother that causes a disaster for the family. Thus, two different women are juxtaposed. Mary figure is the guide in saint's legend because she is "to deflect all criticisms of women derived from the behaviour of Eve and to model appropriate feminine behaviour" (Hallissy, 1993, p. 17). In this case, Constance is presented as the Mary-like figure, whereas Alla's mother, Donegild is the Evelike figure, as she wants to torment Constance: "That I moot be thy tormentour, or deye On shames deeth; ther is noon oother weye" (Chaucer, 1957, Lines 817-18). The female character needs the help of a divine power, as Constance is saved by Virgin Mary upon her prayer and finds herself in Syria. When King Alla goes to Rome to ask for penance and forgiveness, he meets Constance and Maurice that are brought back to Italy by the Roman army. Thus, Constance re-unites with her husband and her father. She tells her father: "I am youre doghter Custance quod she, That whilom ye han sent unto Surrye. . . Sende me namoore unto noon hethenesse, But thonketh my lord here of his kyndenesse" (Chaucer, 1957, Lines 1107-13). As a pious Christian, she does not want to live in the land of the "Godless" anymore (emphasis added). In the end, she goes to England with King Alla but returns to Italy upon Alla's death.

As can be seen, the female character Constance experiences constant persecution in the tale. Bloomfield comments on this persecution as follows: "Constance undergoes one punishment after another although God is always with her. The piling up of unhappiness for our hapless heroine seems to have no end, and some kind of aesthetic balance is used to maintain a sense of order. Two mothers-in-law turn against her and succeed in separating her from her husbands" (1972, p. 387). She is constantly tested. The sultan's mother sees her as a threat to "old lawe' and uses legal punishment to get rid of her" (Scheps, 1974, p. 292). In this respect, Constance is "accused of crimes which she is innocent, suffers for the misdeeds of others, and is herself the victim of their crimes against her" (Scheps, 1974, p. 292). 
These three tales have something in common: the problematic representation of gender roles. Dorigen is under the influence of romance and the courtly love tradition, whereas the daughter of Virginius and Constance are under the influence of the saint's legend tradition. Dorigen has a happy marriage until Arveragus goes away. When she meets her husband, she becomes really elated and the union of a patriarchal family is presented. Different from Dorigen, Virginius' daughter is slain by her father so that she will not be ravished. The male figure adjudges that she should be slain to protect her maidenhood. This issue of maidenhood is common in both Dorigen and the daughter. Both of these characters are worried about maidenhood, name, and honor. Constance is under the influence of patriarchy, but she is a stronger character as compared to the daughter since she is always helped by God, Christ, and Virgin Mary. She experiences constant male persecution; however, she succeeds in each testing and becomes a role model with her saint-like life.

\section{Conclusion}

In conclusion, Chaucer presents a panorama of his society and deals with a wide variety of issues in The Canterbury Tales. This study has demonstrated that the problematic representation of gender and female characters is one of these major issues, as he portrays female characters in various challenging situations in the three selected tales, namely "The Franklin's Tale," “The Physician's Tale," and "The Man of Law's Tale." In these tales, Dorigen is depicted as the loyal wife; the daughter as the self-sacrificing daughter; and Constance as the saint-like figure that is saved each time by divine power.

This study has also exposed that these pivotal female characters in these tales are idealized and defined by the male discourse and given patriarchal attributes. If they cling to these values, they are valued, but once they attempt to trespass the limits of patriarchy, they are labelled as Eve-like. Their lives and decisions are under the strong influence of men, common to the female characters in these tales, as has been discussed through specific references to the primary sources and relevant secondary sources throughout this study. All in all, the discussion of these women's portrayal in these tales reveals how women were perceived in the Medieval period, and how they were under the strict control of patriarchy, which silenced and suppressed women, denying them the right to shape their lives.

\section{References}

Baker, D. C. (1961). A crux in Chaucer's Franklin's Tale: Dorigen's complaint. Journal of English and Germanic Philology, 60, 56-64.

Blalock M. and Larson, W. (2003). General introduction. In: Reames S. (Ed.), Middle English legends of women saints (pp. 1-22). Kalamazoo, Michigan: Medieval Institute Publications.

Bloch, R. H. (1989). Chaucer's maiden's head: The Physician Tale and the poetics of virginity. Representations, 28, 113-134.

Bloomfield, M. W. (1972). The Man of Law's Tale: A tragedy of victimization and a Christian comedy. PMLA, 87 (3), 384-390.

Butler, J. (1988). Performative acts and gender constitution: An essay in phenomenology and feminist theory. Theatre Journal, 40(4), 519-531. doi:10.2307/3207893.

Chaucer, G. (1957). The works of Geoffrey Chaucer. Boston, Massachusetts: Houghton Mifflin.

Chao, M. (2007). Female voice in Geoffrey Chaucer's Canterbury Tales. General Education and Transdisciplinary Research, 1(2), 75-92.

Fichte, J. O. (1983). Incident - history - exemplum - novella: The transformation of history in Chaucer's Physician's Tale. Florilegium, 189-207. https://journals.lib.unb.ca/index.php/flor/article/view/19342

Furnish, S. (2007). Thematic structure and symbolic motif in the middle English Breton lays. Traditio, 62, 83-118. doi:10.1017/S0362152900000544.

Hallissy, M. (1993). Clean maids, true wives, steadfast widows: Chaucer's women and medieval codes of conduct. Connecticut: Greenwood Press.

Lennox, S. (1991). Some proposals for feminist literary criticism. Women in German Yearbook, 7, 91-97. doi:10.1353/wgy.1991.0002. 
Mann, L. A. (1966). Gentilesse and the Franklin Tale. Studies in Pbilology, 63 (1), 10-29. http://www.jstor.org/stable/4173516

Martin, J. H. (1972). Love's fools: Aucassin, Troilus, Calisto and the parody of the courtly lover. London: Spain.

Middleton, A. (1973). The Physician's Tale and Love's Martyrs: Ensamples Mo Than Ten as a Method in the Canterbury Tales. The Chaucer Review, 8(1), 9-32. http://www.jstor.org/stable/25093247

Misra, J. (2018). Categories, structures, and intersectional theory. In J. W. Messerschmidt, et al. (Eds.), Gender reckonings: New social theory and research (pp. 111-130). New York: NYU Press. http://www.jstor.org/stable/j.ctt1pwtb3r.12

Nash, K. (1994). The feminist production of knowledge: Is deconstruction a practice for women? Feminist Review, 47, 65-77. https://doi.org/10.1057/fr.1994.22

Nowlin, S. (2006). Between precedent and possibility: Liminality, historicity, and narrative in Chaucer's The Franklin's Tale. Studies in Philology, 103(1), 47-67. http://www.jstor.org/stable/4174838

Scheps, W. (1974). Chaucer's Man of Law and the Tale of Constance. PMLA, 89(2), 285-295. doi:10.2307/461451.

Schofield, W. H. (1901). Chaucer's Franklin Tale. PMLA, 16(3), 405-449. doi:10.2307/456483.

Warden, T. L. (2001). Medieval courtly love: The links between courtly love, Christianity, and the roles of women: Tennyson and Morris (Master's thesis, East Tennessee State University, Tennessee).

Yuval-Davis, N. (2009). Intersectionality and feminist politics. In M. T. Berger and K. Guidroz (Eds.), The Intersectional approach: Transforming the academy through race, class, and gender (pp. 44-60). Chapel Hill: University of North Carolina Press. http://www.jstor.org/stable/10.5149/9780807895566_berger.6

\section{Acknowledgments}

*I am grateful to Prof. Dr. Huriye Reis from the Department of English Language and Literature at Hacettepe University, Ankara for her enormous contribution to my understanding of Chaucer's work during my doctoral studies. 